\title{
Hepatitis C Virus Infection and Mixed Cryoglobulinemia
}

\author{
Gianfranco Lauletta, ${ }^{1}$ Sabino Russi, ${ }^{1}$ Vincenza Conteduca, ${ }^{1}$ and Loredana Sansonno ${ }^{2}$ \\ ${ }^{1}$ Department of Biomedical Sciences and Human Oncology, Section of Internal Medicine and Clinical Oncology, Liver Unit, \\ University of Bari Medical School 70124, Bari, Italy \\ ${ }^{2}$ Department of Biomedical Sciences, University of Foggia, 71122 Foggia, Italy
}

Correspondence should be addressed to Gianfranco Lauletta, lauletta@dimo.uniba.it

Received 11 May 2012; Accepted 11 June 2012

Academic Editor: Domenico Sansonno

Copyright (๑) 2012 Gianfranco Lauletta et al. This is an open access article distributed under the Creative Commons Attribution License, which permits unrestricted use, distribution, and reproduction in any medium, provided the original work is properly cited.

Hepatitis $\mathrm{C}$ virus (HCV) chronic infection is recognized as the major cause of mixed cryoglobulinemia (MC). Its persistence represents a continuous stimulus for host immune system with production of circulating immune complexes (ICs), one-third of them with cryoprecipitate property. Several factors contribute to the biological activities of ICs, many of which are not completely known. Among them, complement factors play a crucial role in the cold-insoluble ICs-mediated vasculitis, involving primarily small blood vessels in different tissues including skin, kidney, peripheral, and central nervous system. Liver represents the major target of HCV infection with inflammatory infiltrates, resembling secondary lymphoid follicles. Cytokine like CXCL13 contribute to B-cell homing in intraportal lymphoid aggregates, in which B-cell clonal selection may arise. B-cell clonal expansion starts as an antigen-driven event and expands towards indolent and malignant B-cell proliferation. Occurrence of intrahepatic Bcell clonalities correlates with extrahepatic clinical manifestations of HCV infection. In this context, cryoglobulinemic patients should be considered a peculiar HCV-infected population that needs a clinical multidisciplinary approach and more articulated therapeutic measures.

\section{Introduction}

Hepatitis C virus (HCV) is a Flaviviridae family member, genus Hepacivirus, infecting about 200 million people worldwide [1]. About $80 \%$ of $\mathrm{HCV}$-infected patients develop chronic hepatitis. Among them, 10-20\% evolve into cirrhosis, while $1-5 \%$ of cirrhotic patients display an hepatocarcinoma [2]. Although HCV is primarily hepatopathic, its clinical feature is characterized by the emergence of several extrahepatic manifestations. Mixed cryoglobulinemia (MC), recognized as the most common HCV-induced extrahepatic disease, is an immune-complex-mediated vasculitis involving small vessels characterized by an underlying B cell proliferation [3]. Since B-cell clonal expansion is hallmark of MC, B-cell malignant evolution may reflect the occurrence of additional genetic accidents [4].

Here, we will discuss the currently accepted pathogenetic mechanisms that characterize cryoglobulinemic vasculitis with its peculiar clinical manifestations, the molecular events proposed to explain the potentially malignant evolution, and the current therapeutic approaches.

\section{The Virus}

$\mathrm{HCV}$ genome is about $9,600 \mathrm{~kb}$ length and encodes for a single protein from an open reading frame of over 9024 nucleotides. This single polyprotein is subsequently cleaved into several structural and nonstructural proteins. The structural proteins are represented by core and two envelope proteins (E1 and E2), starting from the $5^{\prime}$ end [1]. The ion channel protein $\mathrm{p} 7$ derives from E2 cleavage [5] and is followed by the six nonstructural proteins, namely, NS2, NS3, NS4A, NS4B, NS5A, and NS5B. In addition, another protein called $\mathrm{F}$ or ARFP can be produced from a frameshift of the core protein [6]. At the $5^{\prime}$ and $3^{\prime}$ ends of HCV genome there are two untranslated regions (UTR); the $5^{\prime}$ UTR is a highly conserved region constituted by 341 nucleotides that contains an internal ribosome entry site 
(IRES) for translation. The $3^{\prime} \mathrm{UTR}$ is constituted by 200 to 235 nucleotides and contains a variable region, a poly U/UC stretch and a highly conserved 98 nucleotide sequence [7].

During the replicative stage, HCV genomic RNA is transcribed into a complementary RNA strand. This "negative" strand constitutes a template for a new genomic synthesis and its identification represents a convincing evidence of active replication [8]. Viral proteins are the result of a co- and post-translational cleavage of a single polyprotein, while host peptidases catalyze the cleavage of structural proteins. HCV particles form a membrane-associated replication complex; after genome amplification and protein expression, progeny virions are assembled and released $[9,10]$ (Figure 1).

\section{The Cryoglobulins}

Cryoglobulins are immunoglobulins (Igs) characterized by insolubility at low temperature (below $37^{\circ} \mathrm{C}$ ) and redissolving after warming. The first observation of a cryoprecipitation was registered in the serum of a patient affected by multiple myeloma in 1933 [11], even if the term "cryoglobulin" was introduced by Lerner and Watson in 1947 [12]. Meltzer and Franklin first described the cryoglobulinemic syndrome in 29 patients associating cryoglobulin production to a symptomatologic clinical triad characterized by purpura, arthralgias, and weakness [13], with increased serum levels of rheumatoid factor (RF) and/or organ dysfunction.

On the basis of their immunochemical composition, cryoglobulins are classified as single (type I) or mixed (type II and III) [14]. Type I cryoglobulinemia consists of a monoclonal Ig, more frequently of IgM or IgG isotype. IgM cryoglobulins occurs in almost $6 \%$ of malignant IgM paraproteinemias, whereas IgG cryoglobulins characterize almost $2 \%$ of all myelomas. Type I IgA cryoglobulins are rare [15]. Type II MC accounts for 50-60\% of all cryoglobulins. It comprises an $\operatorname{IgM}$ monoclonal component, frequently mounting light $\mathrm{k}$ chains, and polyclonal IgG. IgM molecules display a rheumatoid factor activity capable of reacting with intact IgG and/or its $\mathrm{F}(\mathrm{ab}) 2^{\prime}$ fragment [16]. No monoclonal component is contained in type III MC that accounts for 30 $40 \%$ of cryoglobulins. Some authors have noted that type III $\mathrm{MC}$ may represent a transition form evolving into type II MC [17].

Mixed cryoglobulins are potentially present in the course of connective tissue and autoimmune diseases, and chronic infections $[18,19]$. The term "essential" defines cryoglobulinemic syndromes without an underlying identifiable disease. It is now accepted that the majority of them occurs in HCV chronically infected patients [20] as the result of specific interactions between the virus and the host immune system [21]. The clinical picture is characterized by the cutaneous manifestations ranging from palpable purpura of lower limbs to chronic torpid cutaneous ulcers more frequent in the supramalleolar regions. Skin reactions include Raynaud's phenomenon, livedo reticularis, urticarial, and edema (Figure 2). Arthralgias more frequently involve the hands and knees symmetrically. Weakness is nearly always present. Kidney, liver, and nervous system are frequently involved.
Renal injury may complicate MC in almost $30 \%$ of cases and in $20 \%$ of whom nephropathy is present at the diagnosis [22-24]. Clinical features like hypertension, proteinuria, microhematuria, red blood cell casts, and renal failure have an indolent course in about $50 \%$ of cases. Less common are nephritic (14\%) or nephrotic (21\%) syndromes [25]. A defined picture of cryoglobulinemic glomerulonephritis evolve into chronic renal failure in $14 \%$ of cases after a mean followup of 6 years [26].

Although kidney involvement is a common feature of systemic vasculitis, cryoglobulinemic nephropathy is considered as a distinct clinical and pathological entity and the etiological role of $\mathrm{HCV}$ has been extensively investigated [27]. Type I membranoproliferative glomerulonephritis is predominantly associated with $\mathrm{HCV}$ infection $[28,29]$. The mechanism of HCV-induced renal damage is unclear. HCV core protein resulted homogeneously distributed along the glomerular capillary wall and tubulo-interstitial blood vessels [30] in association with an anticore activity, suggesting a major role of these immune complexes in the pathogenesis of renal damage [31].

The involvement of the nervous system in the course of HCV-related MC ranges from $17 \%$ to $60 \%$ [32]. Sometimes, peripheral neuropathy can represent the first clinical sign of cryoglobulinemia [33]. Peripheral nervous system involvement presenting with sensory-motor neuropathy especially of the lower limbs, is often characterized by paresthesias with loss of strength, pain, and burning sensations [34]. Less frequent is central nervous system involvement, characterized by transient dysarthria, hemiplegia, and confusional state [35].

Liver is involved in almost $70 \%$ of cases, often with a histopathologic picture of chronic active hepatitis with or without cirrhosis $[36,37]$.

Less common clinical pictures of cryoglobulinemic vasculitis are represented by gastrointestinal $(2-6 \%)$ and pulmonary (5\%) involvement. Intestinal ischaemia may arise with acute abdominal pain; intestinal perforation is also described as well as symptoms that mimic cholecystitis and/or pancreatitis [38]. Interstitial pneumopathy may characterize patients displaying dyspnea and dry cough, whereas an acute alveolar haemorrhage with haemoptysis, respiratory failure, and a radiologic demonstration of multiple infiltrates is rare $[39,40]$.

\section{HCV Chronic Infection and MC}

After the identification of HCV as the etiologic agent of non$\mathrm{A}$, non-B chronic hepatitis and the availability of a serologic test for the demonstration of IgG anti-HCV in the early 1990s, several authors described an intriguing association between HCV infection and "essential" MC, apart from some geographical differences [36, 41, 42]. These association was subsequently confirmed by detection of viral genome in sera of cryoglobulinemic patients with a selective concentration in cryoprecipitates $[21,43]$. Incidence of HCV infection in MC ranges from 40 to $90 \%$ [22]. Otherwise, HCV-negative MC accounts for about 5-10\% [44]. 


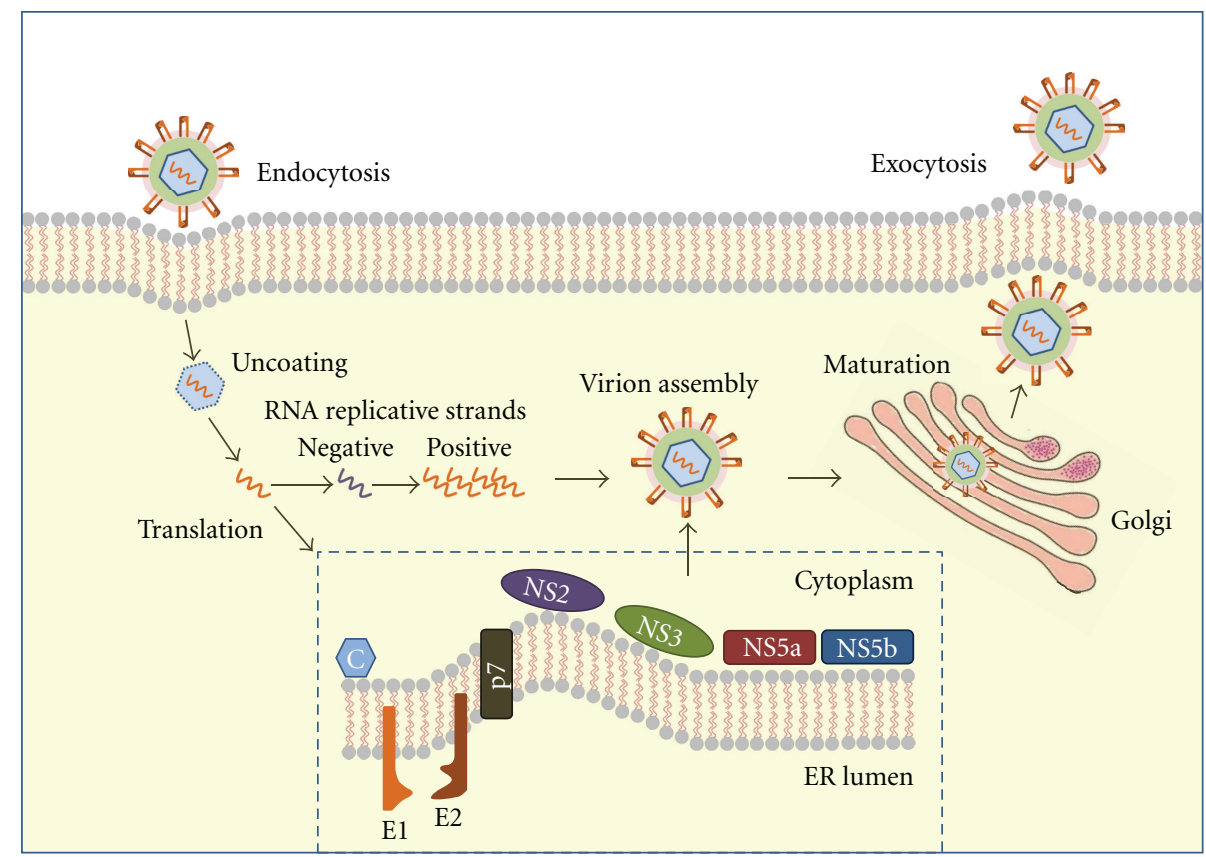

FiguRE 1: HCV life cycle in host cell. During the replicative stage, after endocytosis, HCV genomic RNA is transcribed into a complementary (negative) RNA strand. After genome amplification and structural and nonstructural viral protein expression, progeny virions are assembled and released.

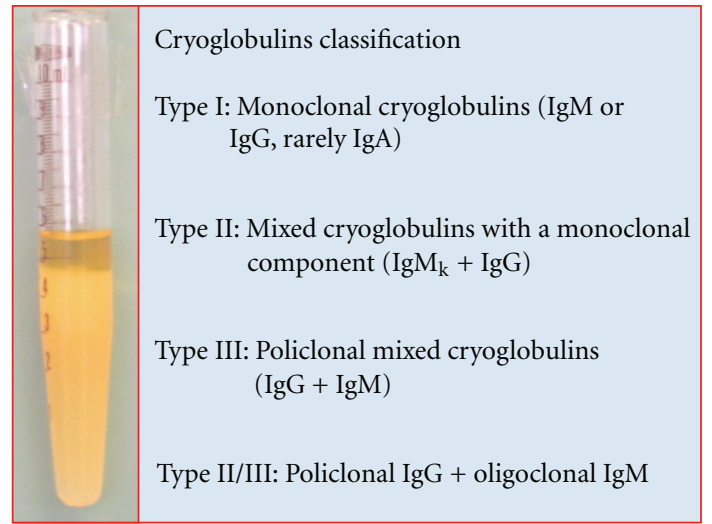

(a)

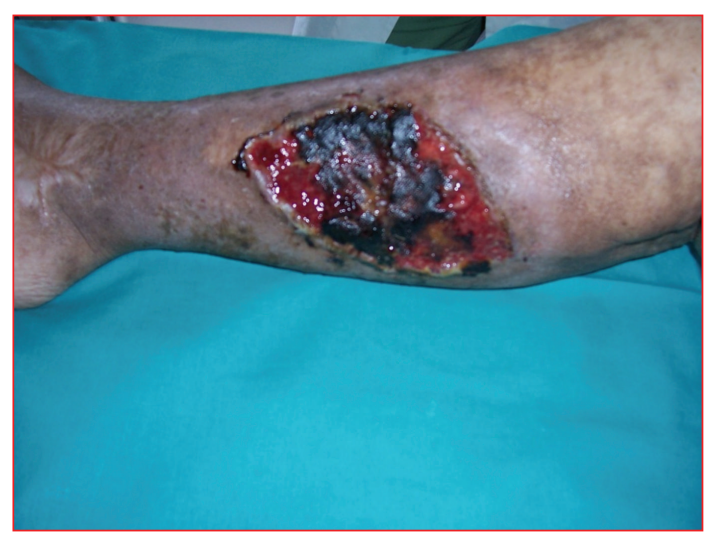

(c)

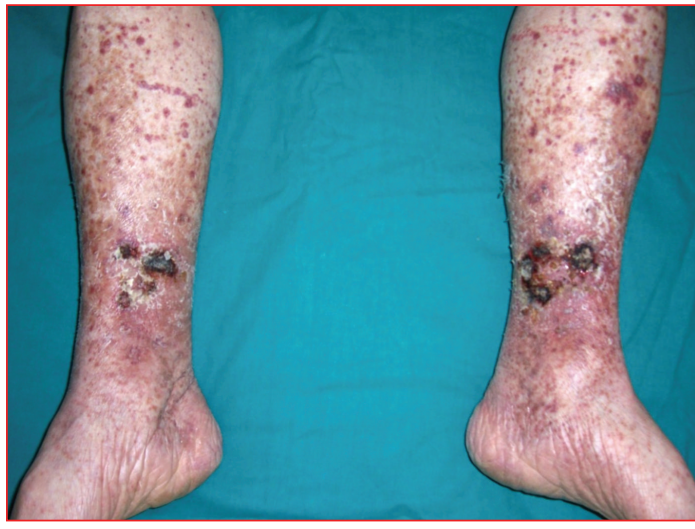

(b)

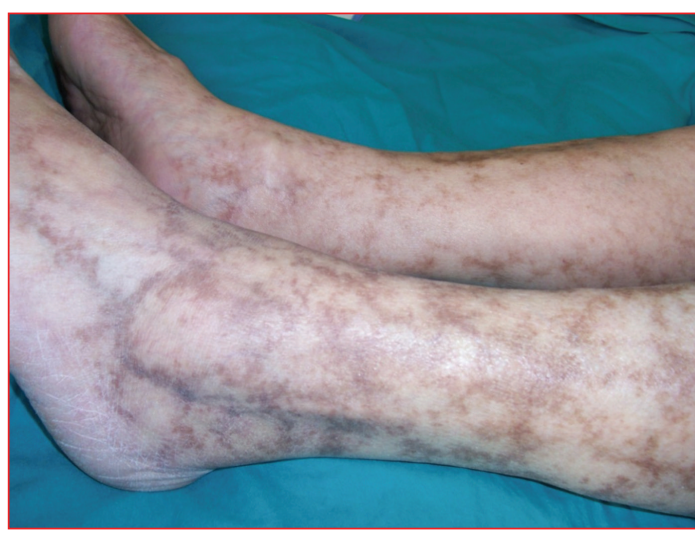

(d)

Figure 2: Clinical aspects of cryoglobulinemia. (a) Cryoglobulins classification; (b) lower limbs purpuric manifestations; (c) cutaneous ulcers; (d) livedo reticularis. 


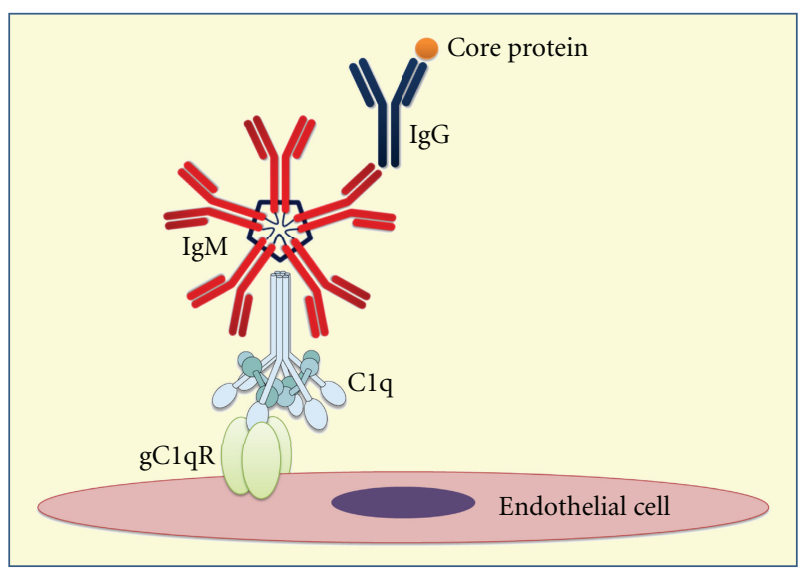

FIgure 3: Pathogenetic model of cryoglobulinemic tissue damage. $\mathrm{HCV}$ core protein, which has been detected in cryoprecipitate immune complexes, interacts with $\mathrm{Clq}$ protein and the receptor for the globular domain of $\mathrm{Clq}$ protein $(\mathrm{gClq}-\mathrm{R})$ on the surface of both circulating blood and endothelial cells. Cryoprecipitating immune complexes, including gClqR complexed to $\mathrm{HCV}$ core and C1q proteins, bind in turn IgM molecules with rheumatoid factor activity linked to anti-HCV IgG.

The intrinsic mechanism by which HCV promotes cryoglobulin production is unclear. Virus persistence, therefore, may represent a continuous stimulus for host immune system unable to produce neutralizing antibodies $[45,46]$. In this context, cryoglobulins may represent the product of virus-host interactions in $\mathrm{HCV}$-infected patients, whereas the production of IgM molecules with RF activity is a crucial event in the cryoprecipitating process [22]. The majority of these IgM molecules are almost always associated with light chain cross-idiotype 17.109 and heavy chain cross idiotype G6 [47]. These cross-idiotypes are considered as the product of a restricted expression of germline genes [19].

It has been hypothesized that the composition of ICs in the course of chronic HCV infection includes IgM17.109 RF molecules which bind anti-HCV IgG [48]. Among viral antigens, the core protein plays a crucial role in cryoglobulins constitution being the relevant ligand for $\operatorname{IgG}$ [31]. Interaction between HCV and lymphocytes is capable of modulating cell functions; in particular, an in vivo activation and expansion of CD5-positive B cells has been considered the major source of IgM RF molecules in type III MC $[49,50]$. Therefore, it has been postulated that an initial activation of these cells may be followed by the emergence of a dominant clone that synthesize a monoclonal RF supporting the development of type II MC after a transition phase in which an IgM clonal heterogeneity may define a type II-type III variant [17]. In a subset of HCV-positive patients with MC, a clonal expansion of $\mathrm{IgM}^{+} \mathrm{CD} 27^{+} \mathrm{B}$ cells expressing hyper-mutated RF-like Ig has been demonstrated in peripheral blood in association to $V_{H} 1-69 / J_{H} 4$ and $V_{H} 3-20$ gene segment restriction [51]. These findings have been interpreted as a B-cell proliferation induced by specific antigen stimulation, thus sustaining the notion that persistent B-cell stimulation may represent a first step to malignant evolution.
A crucial role in the composition of cryoprecipitating ICs is played by complement system. Generally, complement binding to setting up ICs decreases the size maintaining them in solution [52]. Mean levels of C3 and C4 fractions in the soluble phase of MC patients' sera correlate to very low amounts in cryoprecipitates thus suggesting the existence of two different compartments characterized by a distinct complement activation [22]. On the contrary, C1q protein and $\mathrm{C} 1 \mathrm{q}$ binding activity result significantly enriched in the cryoprecipitates [31]. These data support the hypothesis that an efficient engagement of $\mathrm{Clq}$ protein by cryoglobulins may represent a crucial factor in the pathogenetic pathway of MC.

HCV-encoded core protein interacts directly with the receptor for the globular domain of $\mathrm{Clq}$ protein (gC1q-R) representing an efficient way to affect the host T- and Bcell immunity. This interaction has been considered capable of modulate T-cell immune response and, on the other hand, circulating HCV core protein engagement with gC1q$\mathrm{R}$ expressed on the surface of B-lymphocytes may represent a direct way by which the virus can affect host immunity [5355]. The wide expression of $\mathrm{gClq}-\mathrm{R}$ on the surface of both circulating blood immunocytes and endothelial cells may determine a specific binding to $\mathrm{HCV}$ core protein-containing ICs.

Recently, it has been demonstrated that MC patients display higher levels of soluble gClq- $\mathrm{R}$ that reflects a higher specific mRNA expression in blood mononuclear cells [56]. It was also demonstrated that soluble $\mathrm{gCl}$ q- $\mathrm{R}$ circulates as a complexed form containing both $\mathrm{Clq}$ and $\mathrm{HCV}$ core protein in two different binding sites of the molecule (Figure 3).

C4d, a low-molecular-weight fragment derived from the cleavage of $\mathrm{C} 4$ complement fraction following classic complement pathway activation, results are lower in MC patients' sera than in chronic HCV carriers or in healthy subjects [56]. Otherwise, C4d fragment deposits characterize almost all skin biopsy samples of cryoglobulinemic vasculitis. These data lead to hypothesize that low circulating C4d levels are the result of sequestered fragments in the vascular bed. In vitro experiments showed a peculiar property of MC patients in that, in step with HCV core inhibition of the peripheral blood lymphocytes (PBL) proliferative response, large amounts of soluble $\mathrm{gClq}-\mathrm{R}$ were found in culture supernatants. It can be inferred that gClq-R synthesis and its release from PBL are HCV core mediated and negatively regulated by cell proliferation [56].

In conclusion, in the presence of high levels of circulating $\mathrm{gClq}-\mathrm{R}, \mathrm{HCV}$ core protein can exacerbate the inflammatory condition by activation of complement cascade thus determining endothelial cell activation starting an in situ inflammatory response. From a biological point of view, clinical response to antiviral therapy is characterized by a significant reduction of soluble $\mathrm{gClq}-\mathrm{R}$ associated to increased levels of C4d and lower viral load [56].

\section{HCV Infection and Lymphoid Cells}

$\mathrm{HCV}$ is capable of directly modulate $\mathrm{B}$ - and T-cells functions [57]. The monoclonal IgM RF production can be considered as the expression of a single dominant clone following the 


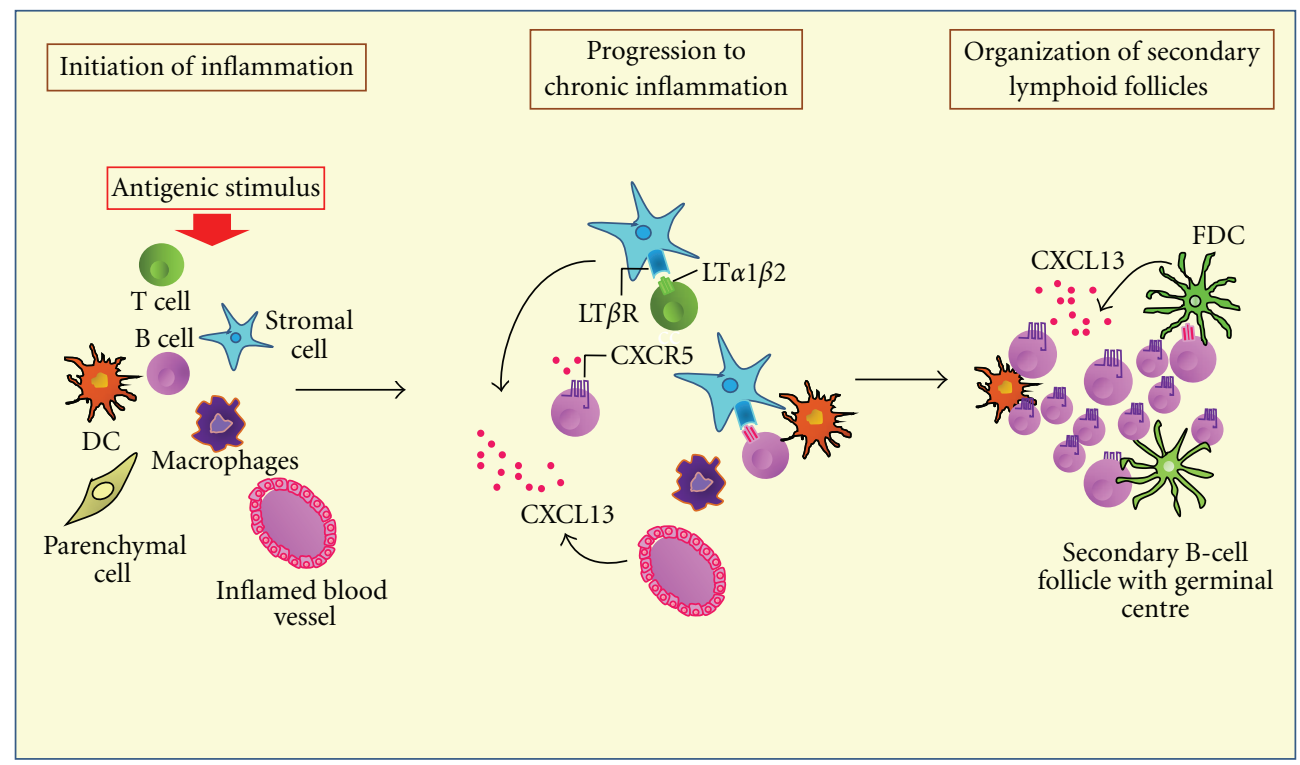

CXCL13: CXC motif chemokine ligand 13 CXCR5: chemokine receptor 5 LT $\beta$ R: lymphotoxin- $\beta$ receptor
LT $\alpha 1 \beta 2$ : lymphotoxin- $\alpha 1 \beta 2$

DC: dendritic cell

FDC: follicular dendritic cell

FIGURE 4: Schematic representation of chronic inflammation and organization of secondary lymphoid follicles in HCV chronic infection. The ability of HCV to chronically persist in the host may represent a continuous stimulus for the immune system resulting in B-cell oligo/monoclonal expansions with selective advantage to clones depending on antigen stimulation. Some chemokines may play a crucial role in the establishment of an adequate microenvironment for activation and expansion of B-lymphocytes in response to signals provided by antigen-presenting cells. Among them, CXC motif chemokine ligand 13 (CXCL13) and its chemokine receptor 5 (CXCR5) are important for secondary lymphoid tissue development and distribution of lymphocytes within microenvironments. CXCL13 is released by endothelial and stromal cells mediated by lymphotoxin- $\beta$ receptor (LT $\beta$ R) signaling and contributes to lymphoid homing in the liver by the creation of a favourable microenvironment sustaining focal B-cell aggregation similar to lymphoid follicles.

initial stimulation, thus supporting type II MC development $[17,50]$. The ability of HCV to chronically persist in the host may represent a continuous stimulus for the immune system resulting in B-cell oligo/monoclonal expansions (Figure 4) [4].

HCV recognizes different binding molecules on cells surface that are not completely identified. Among them, the most known are CD81 [58], scavenger receptor class B type I [59], and low-density lipoprotein receptor [60]. MC patients are distinctly characterized by higher levels of cell-associated viral load, because a significant enrichment of HCV RNA in PBL has been demonstrated [61]. This peculiar feature may be considered as the result of a higher density [62] and/or polymorphism of receptor genes $[63,64]$, whereas direct infection and replication of $\mathrm{HCV}$ in B cells may promote lymphocyte proliferation [65].

The presence of HCV minus-strand RNA is the key factor to demonstrate an active viral replication in cells, whereas the presence of plus-strand RNA may indicate a possible contamination by circulating virions. By means of a highly specific and sensitive method for the detection of HCV RNA minus strand an active viral replication in lymphoid cells from MC patients has been demonstrated [66]. These results suggest that there is a direct correlation between HCV active infection of lymphoid cells and MC. In a cohort of MC patients, $\mathrm{PBL}$ may be considered another $\mathrm{HCV}$ productive infection compartment, in addition to the liver, representing a circulating reservoir of HCV infection [67].

Although no specific viral protein has been indicated as BCR ligand [68], analysis of Ig variable gene (IgV) sustain an antigen-driven B-cells expansion. IgV heavy and light chain genes are always mutated as occurs in germinal or post-germinal center origin of $B$ cells $[69,70]$. The presence of hypermutated $\mathrm{IgV}$ genes capable of recognizing a single epitope suggests that they arise randomly from the B cell pool [70] selected for non-self-antigens. Otherwise, most Bcell expansions show a CDR3 with significant homology to RF-CDR3 [68, 70], suggesting a distinct pathogenesis since these B-cell clonalities derive from precursors with autoIgG specificity [71]. It has been demonstrated that in some $\mathrm{HCV}$-positive $\mathrm{MC}$ patients, $\mathrm{BCR}$ recognize IgG-Fc and $\mathrm{HCV}$ NS3 domains, suggesting that its specificity derives from a cross-reactivity between a virus-associated epitope and IgG autoantigen [72]. This mechanism may also contribute to the virus enrichment on the lymphoid cells in MC patients, thus conditioning RF B cells to undergo cell cycle and secrete RF molecules [73].

\section{HCV and Lymphoproliferation}

In the course of B-cell proliferation, several mutants may derive from $\mathrm{IgV}$ genes somatic mutations. By means of 
polymerase chain reaction technique (PCR) directed against the variable-determining-joining region (VDJ), it is possible to identify the combination of $\mathrm{N}$ regions along with different $\mathrm{DH}$ and $\mathrm{JH}$ regions. This unique combination represents a clonal marker of cell progeny. The application of this method leads to the demonstration that B-cell clonal expansions are present in the liver tissue of almost $90 \%$ of $\mathrm{HCV}$-positive MC patients if compared with blood and bone-marrow compartments [73].

HCV chronic infection is characterized by the development of inflammatory infiltrates involving the portal tracts. These infiltrates often appear as follicle-like structures resembling a germinal center functionally active [74, 75]. VDJ pattern obtained from these patients resulted in oligoclonality to monoclonality, suggesting that intrahepatic Bcell expansions raise from very few or single cells. In addition, each focus may derive from different $\mathrm{B}$ cell of the polyclonal repertoire, resulting in the development of unrelated clones.

The occurrence of intrahepatic B-cell clonal expansions profoundly influenced the clinical spectrum of HCV infection, since it was associated invariably with extrahepatic manifestations including cryoglobulinemia, high serum levels of RF activity, monoclonal gammopathy of undetermined significance, and also B-cell non Hodgkin lymphoma. Clonal expansions display a restricted $\mathrm{V}$ gene usage, thus confirming a direct relation with clinical manifestations [76]. In addition, sequence analyses of IgH CDR3 gene segments of intraportal B-cell clonalities revealed a wide range of variations, suggesting that they are the result of an antigendriven response [77]. These findings lead to hypothesize that B-cell clones start expanding in the liver as a consequence of an upregulated IgH-VDJ mutational activity and then migrates in the circle and also bone marrow [76].

However, the relationship between emergence and persistence of intrahepatic or circulating B-cell clones and $\mathrm{HCV}$ infection remains unclear. Several pieces of evidence indicate that some chemokines can play a crucial role in the establishment of an adequate microenvironment for activation and expansion of B-lymphocytes in response to signals provided by antigen-presenting cells [78]. Among them, CXC ligand 13 (CXCL13), also known as B-cell attracting chemokine 1 or B-lymphocyte chemoattractant, is important for secondary lymphoid tissue development and distribution of lymphocytes within microenvironments [79]. High serum levels of CXCL13 protein in MC patients paralleled those of specific mRNA expression in liver and skin tissues, suggesting that this chemokine may represent a key factor in the pathogenesis of cryoglobulin-induced damage [80]. CXCL13 contributes therefore to lymphoid homing in the liver by creating a local microenvironment sustaining focal B-cell aggregation similar to lymphoid follicles (Figure 3).

In addition, B-cell enrichment may be the result of the presence of some signals enhancing cell survival [81]. B-lymphocyte activating factor (BAFF), also known as Blymphocyte stimulator (BLyS), is expressed and secreted by activated monocytes, macrophages, and dendritic cells. Serum BAFF levels results increased in patients with chronic $\mathrm{HCV}$ infection, as well as in other autoimmune diseases like systemic lupus erythematosus and rheumatoid arthritis, and this was correlated to autoimmune and vasculitic manifestations. The increased levels of BAFF may modulate the sensitivity of B cells to apoptosis prolonging their survival, thus representing another possible factor in the clonal B-cell expansion [82].

\section{Management of MC}

The main goals of the therapy of MC are represented by: (a) eradication of HCV infection; (b) deletion of the underlying B-cell clonal expansions; (c) depletion of cryoproteins.

Conventionally, in the pre-HCV era, management of MC was based on the use of corticosteroids and immunosuppressive drugs. Following the empirical observation in 1987 of the effectiveness of recombinant IFN- $\alpha$ in 7 patients with "essential" MC [83], and the subsequent demonstration of the pathogenetic role of HCV [21], IFN- $\alpha$ became a rational therapeutic strategy. The introduction of pegylated IFN- $\alpha$ changed the therapeutic scenario of chronic hepatitis C increasing virological responses $[84,85]$ as well as the introduction of ribavirin (RBV), a nucleoside antimetabolite agent [86]. This combination, now considered the standard of care (SoC) for HCV management [87], has been shown to be effective in a remarkable proportion of HCV-related MC patients, resulting in a complete clinical response and sustained virological response (SVR) in 78\% of the patients [88]. In addition, serum levels of $\mathrm{C} 3$ and $\mathrm{C} 4$ complement fractions normalized in $80 \%$ and cryoglobulins disappeared in 56\% of the patients. Even when the antiviral treatment results in resolution of vasculitis, no or only partial improvement in neuropathy and glomerulonephritis is observed, suggesting that the clinical outcome may be conditioned by factors other than the virus [22].

It should also be emphasized that the occurrence of B-cell clonal expansions is able to influence the clinical expression of HCV infection, in that it is consistently associated with extrahepatic manifestations, like MC [76, 89, 90]. Enrichment of B-cell clones in at least three different compartments, namely, liver, bone marrow, and the circulation, and expansion of RF-synthesizing B cells are the biological hallmark of MC [22]. Consequently, deletion of B-cell clonalities may provide a rational way to treat MC. It is well known that CD20 antigen, a transmembrane protein, is selectively expressed on pre-B and mature lymphocytes, and that CD20-positive cells are remarkably expanded and activated in patients with MC $[61,91]$.

Since rituximab (RTX), a chimeric moAb specifically directed to CD20 antigen, has been shown to be therapeutically effective in autoimmune and lymphoproliferative disorders [92-94], it seemed logical to propose its use in HCV-related MC patients refractory to, or relapsing after, conventional antiviral therapy. The first papers about the use of RTX in HCV-related MC $[95,96]$ showed that it is an effective, safe, and well-tolerated treatment for type II MC patients, including those resistant to, or frequently recurring after, previous treatments. However, a not negligible drawback is the frequently increased viremia in the responders. 
On these bases, several subsequent papers have addressed the issue of the use of RTX, alone or in combination with steroids $[97,98]$

In our own study [99], a triple therapeutic combination (pIFN- $\alpha$ plus RBV plus RTX), designated with the acronym PIRR, was administered to $22 \mathrm{HCV}$-positive MC patients, whereas 15 additional patients with the same pathology received, by comparison, pIFN- $\alpha$ plus RBV with the exclusion of RTX. Followup was protracted for 36 months from the end of treatment. Results showed a complete response in $54.5 \%$ of patients treated with PIRR, and only in $33.3 \%$ of those who were given pIFN- $\alpha$ plus RBV without RTX $(P<0.05)$. Even more interesting were the observations that: (a) in the large majority $(83.3 \%)$ of the responders belonging to the PIRR-treated group, a conversion of B-cell populations from oligoclonal to polyclonal was recorded in the liver, bone marrow, and peripheral blood compartments; (b) compared with $40 \%$ of the control group, in all patients of the PIRR group the CR was maintained throughout the follow-up period. Whether RTX should be administered to patients with cryoglobulinemic vasculitis as first- or secondline therapy remains to be established [100].

Of particular interest is the question about MC patients that do not obtain an SVR or those patients showing a continuous cryoglobulin production despite virus eradication. In the first case the use of the new direct-acting antivirals (DAAs) like Telaprevir or Boceprevir (recently approved by the FDA for the treatment of HCV genotype 1 chronic infection) may represent a further therapeutic option [101]. Persistence of MC vasculitis in patients achieving a SVR represents an emerging picture following antiviral and B-cell depletive combined therapies $[102,103]$. In these patients a different immunochemical structure of circulating immunecomplexes may be postulated; the use of corticosteroids, cyclophosphamide, RTX, or ofatumumab (an IgG1k fully humanized CD20 MoAb) may be considered [104].

Therapeutic apheresis is a palliative procedure that can be extremely useful for the treatment of severe, life-threatening vasculitis [100] as well as for the treatment of chronic leg ulcers in patients resistant to other therapies [105].

Others additional therapeutic approaches for MC have been proposed, like tyrosine kinase inhibitor imatinib, antiangiogenic drugs like thalidomide, bortezomib (a proteasome inhibitor), and IL-2, but future controlled studies are required to establish if these agents will improve MC therapy $[106,107]$.

\section{Conclusions}

Although the major role of HCV in the production of cryoglobulins and systemic vasculitis has been clearly established, there are several aspects in the pathogenesis of MC that still require further investigations. Particularly interesting is the B-cell expansion process that starts as a consequence of viral persistence, with preferential involvement of RF-producing B cells. This process seems to occur in a microenvironment like intraportal lymphoid follicles as a result of a distinct selection process probably supported by cytokine signaling sustaining $\mathrm{B}$-cell activation and proliferation.
In this context, some viral proteins like core protein, may directly modulate the mechanism underlying ICs deposition in the vascular bed leading to cryoglobulinemic vasculitis and promote proliferation signals of B cells supporting an active viral replication. In addition, host's genetic factors may represent a crucial factor for the clinical outcome of HCV chronic infection. These complex relations represent the biological basis for a more appropriate treatment of the cryoglobulinemic vasculitis that include antiviral therapy and B-cell depletion even if further studies are necessary for the relapsed-refractory cases in which other pathogenetic mechanisms, often antigen-independent, are involved.

\section{Acknowledgments}

This study was supported in part by a grant from the Italian Medicines Agency (AIFA), funds for independent studies, 2007, Contract no. FARM7SJX and by a grant from University of Bari, Italy.

\section{References}

[1] Q. L. Choo, K. H. Richman, J. H. Han et al., "Genetic organization and diversity of the hepatitis $\mathrm{C}$ virus," Proceedings of the National Academy of Sciences of the United States of America, vol. 88, no. 5, pp. 2451-2455, 1991.

[2] J. H. Hoofnagle, "Course and outcome of hepatitis C," Hepatology, vol. 36, no. 5, supplement 1, pp. S21-S29, 2002.

[3] V. Agnello, "The aetiology of mixed cryoglobulinaemia associated with hepatitis C virus infection," Scandinavian Journal of Immunology, vol. 42, no. 2, pp. 179-184, 1995.

[4] F. Dammacco, D. Sansonno, C. Piccoli, V. Racanelli, F. P. D'Amore, and G. Lauletta, "The lymphoid system in hepatitis C virus infection: autoimmunity, mixed cryoglobulinemia, and overt B-cell malignancy," Seminars in Liver Disease, vol. 20, no. 2, pp. 143-157, 2000.

[5] D. Pavlovic, D. C. A. Neville, O. Argaud et al., "The hepatitis $\mathrm{C}$ virus $\mathrm{p} 7$ protein forms an ion channel that is inhibited by long-alkyl-chain iminosugar derivatives," Proceedings of the National Academy of Sciences of the United States of America, vol. 100, no. 10, pp. 6104-6108, 2003.

[6] J. L. Walewski, T. R. Keller, D. D. Stump, and A. D. Branch, "Evidence for a new hepatitis $\mathrm{C}$ virus antigen encoded in an overlapping reading frame," $R N A$, vol. 7, no. 5, pp. 710-721, 2001.

[7] T. Tanaka, N. Kato, M. J. Cho, and K. Shimotohno, "A novel sequence found at the 3' terminus of hepatitis $\mathrm{C}$ virus genome," Biochemical and Biophysical Research Communications, vol. 215, no. 2, pp. 744-749, 1995.

[8] S. Rosenberg, "Recent advances in the molecular biology of Hepatitis C virus," Journal of Molecular Biology, vol. 313, no. 3, pp. 451-464, 2001.

[9] V. Lohmann, S. Hoffmann, U. Herian, F. Penin, and R. Bartenschlager, "Viral and cellular determinants of hepatitis C virus RNA replication in cell culture," Journal of Virology, vol. 77, no. 5, pp. 3007-3019, 2003.

[10] T. Heller, S. Saito, J. Auerbach et al., "An in vitro model of hepatitis C virion production," Proceedings of the National Academy of Sciences of the United States of America, vol. 102, no. 7, pp. 2579-2583, 2005. 
[11] M. M. Wintrobe and M. V. Buell, "Hyperproteinemia associated with multiple myeloma," Bulletin of the Johns Hopkins Hospital, vol. 52, pp. 156-165, 1933.

[12] A. B. Lerner and C. J. Watson, "Studies of cryoglobulins I: unusual purpura associated with the presence of a high concentration of cryoglobulin (cold precipitable serum globulin)," The American Journal of the Medical Sciences, vol. 214, no. 4, pp. 410-415, 1947.

[13] M. Meltzer and E. C. Franklin, "Cryoglobulinemia-A study of twenty-nine patients. I. IgG and IgM cryoglobulins and factors affecting cryoprecipitability," The American Journal of Medicine, vol. 40, no. 6, pp. 828-836, 1966.

[14] J. C. Brouet, J. P. Clauvel, and F. Danon, "Biologic and clinical significance of cryoglobulins. A report of 86 cases," American Journal of Medicine, vol. 57, no. 5, pp. 775-788, 1974.

[15] A. M. Denman, "Cryoglobulins and the immunopathological manifestations of autoimmune disease," Clinical and Experimental Immunology, vol. 87, no. 2, pp. 169-171, 1992.

[16] A. C. Wang, J. V. Wells, H. H. Fudenberg, and J. Gergely, "Chemical analyses of cryoglobulins," Molecular Immunology, vol. 11, no. 7, pp. 341-345, 1974.

[17] J. D. Tissot, J. A. Schifferli, D. F. Hochstrasser et al., "Twodimensional polyacrylamide gel electrophoresis analysis of cryoglobulins and identification of an IgM-associated peptide," Journal of Immunological Methods, vol. 173, no. 1, pp. 63-75, 1994.

[18] G. Montagnino, "Reappraisal of the clinical expression of mixed cryoglobulinemia," Springer Seminars in Immunopathology, vol. 10, no. 1, pp. 1-19, 1988.

[19] P. D. Gorevic and B. Frangione, "Mixed cryoglobulinemia cross-reactive idiotypes: implications for the relationship of MC to rheumatic and lymphoproliferative diseases," Seminars in Hematology, vol. 28, no. 2, pp. 79-94, 1991.

[20] M. Trendelenburg and J. A. Schifferli, "Cryoglobulins are not essential," Annals of the Rheumatic Diseases, vol. 57, no. 1, pp. 3-5, 1998.

[21] F. Dammacco, D. Sansonno, C. Piccoli, F. A. Tucci, and V. Racanelli, "The cryoglobulins: an overview," European Journal of Clinical Investigation, vol. 31, no. 7, pp. 628-638, 2001.

[22] D. Sansonno and F. Dammacco, "Hepatitis C virus, cryoglobulinaemia, and vasculitis: immune complex relations," The Lancet Infectious Diseases, vol. 5, no. 4, pp. 227-236, 2005.

[23] M. Matignon, P. Cacoub, M. Colombat et al., "Clinical and morphologic spectrum of renal involvement in patients with mixed cryoglobulinemia without evidence of hepatitis C virus infection," Medicine, vol. 88, no. 6, pp. 341-348, 2009.

[24] C. E. Alpers and K. D. Smith, "Cryoglobulinaemia and renal disease," Current Opinion in Nephrology and Hypertension, vol. 17, no. 3, pp. 243-249, 2008.

[25] D. Roccatello, A. Fornasieri, O. Giachino et al., "Multicenter study on hepatitis C virus-related cryoglobulinemic glomerulonephritis," American Journal of Kidney Diseases, vol. 49, no. 1, pp. 69-82, 2007.

[26] A. Tarantino, M. Campise, G. Banfi et al., "Long-term predictors of survival in essential mixed cryoglobulinemic glomerulonephritis," Kidney International, vol. 47, no. 2, pp. 618-623, 1995.

[27] S. Beddhu, S. Bastacky, and J. P. Johnson, "The clinical and morphologic spectrum of renal cryoglobulinemia," Medicine, vol. 81, no. 5, pp. 398-409, 2002.
[28] G. D'Amico, "Renal involvement in hepatitis C infection: cryoglobulinemic glomerulonephritis," Kidney International, vol. 54, no. 2, pp. 650-671, 1998.

[29] D. J. Cordonnier, J. C. Renversez, P. Vialtel, and E. Dechelette, "The kidney in mixed cryoglobulinemias," Springer Seminars in Immunopathology, vol. 9, no. 4, pp. 395-415, 1987.

[30] D. Sansonno, L. Gesualdo, C. Manno, F. P. Schena, and F. Dammacco, "Hepatitis C virus-related proteins in kidney tissue from hepatitis C virus-infected patients with cryoglobulinemic membranoproliferative glomerulonephritis," Hepatology, vol. 25, no. 5, pp. 1237-1244, 1997.

[31] D. Sansonno, G. Lauletta, L. Nisi et al., "Non-enveloped $\mathrm{HCV}$ core protein as constitutive antigen of cold-precipitable immune complexes in type II mixed cryoglobulinaemia," Clinical and Experimental Immunology, vol. 133, no. 2, pp. 275-282, 2003.

[32] F. J. Authier, J. M. Pawlotsky, J. P. Viard, L. Guillevin, J. D. Degos, and R. K. Gherardi, "High incidence of hepatitis $C$ virus infection in patients with cryoglobulinemic neuropathy," Annals of Neurology, vol. 34, no. 5, pp. 749-750, 1993.

[33] C. Ferri, M. Sebastiani, D. Giuggioli et al., "Mixed cryoglobulinemia: demographic, clinical, and serologic features and survival in 231 patients," Seminars in Arthritis and Rheumatism, vol. 33, no. 6, pp. 355-374, 2004.

[34] F. Gemignani, G. Melli, C. Inglese, and A. Marbini, "Cryoglobulinemia is a frequent cause of peripheral neuropathy in undiagnosed referral patients," Journal of the Peripheral Nervous System, vol. 7, no. 1, pp. 59-64, 2002.

[35] L. Origgi, M. Vanoli, A. Carbone, M. Grasso, and R. Scorza, "Central nervous system involvement in patients with HCVrelated cryoglobulinemia," American Journal of the Medical Sciences, vol. 315, no. 3, pp. 208-210, 1998.

[36] F. Dammacco and D. Sansonno, "Antibodies to hepatitis $\mathrm{C}$ virus in essential mixed cryoglobulinaemia," Clinical and Experimental Immunology, vol. 87, no. 3, pp. 352-356, 1992.

[37] D. Saadoun, T. Asselah, M. Resche-Rigon et al., "Cryoglobulinemia is associated with steatosis and fibrosis in chronic hepatitis C," Hepatology, vol. 43, no. 6, pp. 1337-1345, 2006.

[38] B. Terrier, D. Saadoun, D. Sène, S. Scerra, L. Musset, and P. Cacoub, "Presentation and outcome of gastrointestinal involvement in hepatitis $\mathrm{C}$ virus-related systemic vasculitis: a case-control study from a single-centre cohort of 163 patients," Gut, vol. 59, no. 12, pp. 1709-1715, 2010.

[39] M. Ramos-Casals, A. Robles, P. Brito-Zeron et al., "Lifethreatening cryoglobulinaemia: clinical and immunological characterization of 29 cases," Seminars in Arthritis and Rheumatism, vol. 36, no. 3, pp. 189-196, 2006.

[40] S. Retamozo, C. Diaz-Lagares, X. Bosch, S. De Vita, and M. Ramos-Casals, "Life-threatening cryoglobulinemia," in Autoimmune Diseases: Acute and Complex Situations, M. A. Khamashta and M. Ramos-Casals, Eds., pp. 133-162, Springer, London, UK, 2011.

[41] C. Ferri, F. Greco, G. Longombardo et al., "Antibodies to hepatitis $\mathrm{C}$ virus in patients with mixed cryoglobulinemia," Arthritis and Rheumatism, vol. 34, no. 12, pp. 1606-1610, 1991.

[42] V. Agnello, R. T. Chung, and L. M. Kaplan, "A role for hepatitis C virus infection in Type II cryoglobulinemia," New England Journal of Medicine, vol. 327, no. 21, pp. 1490-1495, 1992. 
[43] F. Dammacco, D. Sansonno, V. Cornacchiulo et al., "Hepatitis $\mathrm{C}$ virus infection and mixed cryoglobulinemia: a striking association.," International Journal of Clinical and Laboratory Research, vol. 23, no. 1, pp. 45-49, 1993.

[44] D. Sansonno, A. Carbone, V. De Re, and F. Dammacco, "Hepatitis C virus infection, cryoglobulinaemia, and beyond," Rheumatology, vol. 46, no. 4, pp. 572-578, 2007.

[45] B. Rehermann, "Hepatitis $C$ virus versus innate and adaptive immune responses: a tale of coevolution and coexistence," Journal of Clinical Investigation, vol. 119, no. 7, pp. 17451754, 2009.

[46] L. B. Dustin and C. M. Rice, "Flying under the radar: the immunobiology of hepatitis C," Annual Review of Immunology, vol. 25, pp. 71-99, 2007.

[47] P. P. Chen, S. Fong, F. Goni et al., "Cross-reacting idiotypes on cryoprecipitating rheumatoid factor," Springer Seminars in Immunopathology, vol. 10, no. 1, pp. 35-55, 1988.

[48] D. Sansonno, A. R. Iacobelli, V. Cornacchiulo et al., "Immunochemical and biomolecular studies of circulating immune complexes isolated from patients with acute and chronic hepatitis C virus infection," European Journal of Clinical Investigation, vol. 26, no. 6, pp. 465-475, 1996.

[49] M. P. Curry, L. Golden-Mason, D. G. Doherty et al., "Expansion of innate $\mathrm{CD} 55^{\text {pos }} \mathrm{B}$ cells expressing high levels of CD81 in hepatitis C virus infected liver," Journal of Hepatology, vol. 38, no. 5, pp. 642-650, 2003.

[50] M. M. Newkirk, "Rheumatoid factors: host resistance or autoimmunity?” Clinical Immunology, vol. 104, no. 1, pp. 1$13,2002$.

[51] E. D. Charles, R. M. Green, S. Marukian et al., "Clonal expansion of immunoglobulin $\mathrm{M}^{+} \mathrm{CD} 27^{+} \mathrm{B}$ cells in HCVassociated mixed cryoglobulinemia," Blood, vol. 111, no. 3, pp. 1344-1356, 2008.

[52] G. Lindahl, U. Sjobring, and E. Johnsson, "Human complement regulators: a major target for pathogenic macroorganisms," Current Opinion in Immunology, vol. 12, no. 1, pp. 44$51,2000$.

[53] D. J. Kittlesen, K. A. Chianese-Bullock, Z. Q. Yao, T. J. Braciale, and Y. S. Hahn, "Interaction between complement receptor $\mathrm{gClqR}$ and hepatitis $\mathrm{C}$ virus core protein inhibits T-lymphocyte proliferation," Journal of Clinical Investigation, vol. 106, no. 10, pp. 1239-1249, 2000.

[54] Z. Q. Yao, S. Ray, A. Eisen-Vandervelde, S. Waggoner, and Y. S. Hahn, "Hepatitis C virus: immunosuppression by complement regulatory pathway," Viral Immunology, vol. 14, no. 4, pp. 277-295, 2001.

[55] Z. Q. Yao, D. Prayther, C. Trabue, Z. P. Dong, and J. Moorman, "Differential regulation of SOCS-1 signalling in $\mathrm{B}$ and T lymphocytes by hepatitis C virus core protein," Immunology, vol. 125, no. 2, pp. 197-207, 2008.

[56] D. Sansonno, F. A. Tucci, B. Ghebrehiwet et al., "Role of the receptor for the globular domain of $\mathrm{Clq}$ protein in the pathogenesis of hepatitis $\mathrm{C}$ virus-related cryoglobulin vascular damage," Journal of Immunology, vol. 183, no. 9, pp. 6013-6020, 2009.

[57] D. Saadoun, I. Bieche, T. Maisonobe et al., "Involvement of chemokines and type 1 cytokines in the pathogenesis of hepatitis $C$ virus-associated mixed cryoglobulinemia vasculitis neuropathy," Arthritis and Rheumatism, vol. 52, no. 9, pp. 2917-2925, 2005.

[58] R. Petracca, F. Falugi, G. Galli et al., "Structure-function analysis of hepatitis C virus envelope-CD81 binding," Journal of Virology, vol. 74, no. 10, pp. 4824-4830, 2000.
[59] E. Scarselli, H. Ansuini, R. Cerino et al., "The human scavenger receptor class $\mathrm{B}$ type $\mathrm{I}$ is a novel candidate receptor for the hepatitis C virus," EMBO Journal, vol. 21, no. 19, pp. 5017-5025, 2002.

[60] V. Agnello, G. Ábel, M. Elfahal, G. B. Knight, and Q. X. Zhang, "Hepatitis $\mathrm{C}$ virus and other flaviviridae viruses enter cells via low density lipoprotein receptor," Proceedings of the National Academy of Sciences of the United States of America, vol. 96, no. 22, pp. 12766-12771, 1999.

[61] D. Sansonno, G. Lauletta, M. Montrone, F. A. Tucci, L. Nisi, and F. Dammacco, "Virological analysis and phenotypic characterization of peripheral blood lymphocytes of hepatitis $\mathrm{C}$ virus-infected patients with and without mixed cryoglobulinaemia," Clinical and Experimental Immunology, vol. 143, no. 2, pp. 288-296, 2006.

[62] E. Zuckerman, A. Kessel, G. Slobodin, E. Sabo, D. Yeshurun, and E. Toubi, "Antiviral treatment down-regulates peripheral B-cell CD81 expression and CD5 expansion in chronic hepatitis C virus infection," Journal of Virology, vol. 77, no. 19, pp. 10432-10436, 2003.

[63] J. Laporte, C. Bain, P. Maurel, G. Inchauspe, H. Agut, and A. Cahour, "Differential distribution and internal translation efficiency of hepatitis $\mathrm{C}$ virus quasispecies present in dendritic and liver cells," Blood, vol. 101, no. 1, pp. 52-57, 2003.

[64] B. Kronenberger, C. Sarrazin, W. P. Hofmann et al., "Mutations in the putative HCV-E2 CD81 binding regions and correlation with cell surface CD81 expression," Journal of Viral Hepatitis, vol. 11, no. 4, pp. 310-318, 2004.

[65] S. Pal, D. G. Sullivan, S. Kim et al., "Productive replication of hepatitis $\mathrm{C}$ virus in perihepatic lymph nodes in vivo: implications of HCV lymphotropism," Gastroenterology, vol. 130, no. 4, pp. 1107-1116, 2006.

[66] D. Sansonno, F. A. Tucci, G. Lauletta et al., "Hepatitis C virus productive infection in mononuclear cells from patients with cryoglobulinaemia," Clinical and Experimental Immunology, vol. 147, no. 2, pp. 241-248, 2007.

[67] H. Dahari, A. Feliu, M. Garcia-Retortillo, X. Forns, and A. U. Neumann, "Second hepatitis C replication compartment indicated by viral dynamics during liver transplantation," Journal of Hepatology, vol. 42, no. 4, pp. 491-498, 2005.

[68] V. De Re, S. De Vita, A. Marzotto et al., "Sequence analysis of the immunoglobulin antigen receptor of hepatitis $\mathrm{C}$ virus-associated non-Hodgkin lymphomas suggests that the malignant cells are derived from the rheumatoid factorn-producing cells that occur mainly in type II cryoglobulinemia," Blood, vol. 96, no. 10, pp. 3578-3584, 2000.

[69] C. Hallas, A. Greiner, K. Peters, and H. K. MüllerHermelink, "Immunoglobulin VH genes of high-grade mucosa-associated lymphoid tissue lymphomas show a high load of somatic mutations and evidence of antigendependent affinity maturation," Laboratory Investigation, vol. 78, no. 3, pp. 277-287, 1998.

[70] W. M. Aarts, R. J. Bende, E. J. Steenbergen et al., "Variable heavy chain gene analysis of follicular lymphomas: correlation between heavy chain isotype expression and somatic mutation load," Blood, vol. 95, no. 9, pp. 2922-2929, 2000.

[71] R. J. Bende, W. M. Aarts, R. G. Riedl, D. De Jong, S. T. Pals, and C. J. M. Van Noesel, “Among B cell non-Hodgkin's lymphomas, MALT lymphomas express a unique antibody repertoire with frequent rheumatoid factor reactivity," Journal of Experimental Medicine, vol. 201, no. 8, pp. 1229-1241, 2005.

[72] V. De Re, D. Sansonno, M. P. Simula et al., "HCV-NS3 and IgG-Fc crossreactive IgM in patients with type II mixed 
cryoglobulinemia and B-cell clonal proliferations," Leukemia, vol. 20, no. 6, pp. 1145-1154, 2006.

[73] D. Sansonno, S. De Vita, A. R. Iacobelli, V. Cornacchiulo, M. Boiocchi, and F. Dammacco, "Clonal analysis of intrahepatic B cells from HCV-infected patients with and without mixed cryoglobulinemia," Journal of Immunology, vol. 160, no. 7, pp. 3594-3601, 1998.

[74] K. G. Ishak, "Chronic hepatitis: morphology and nomenclature.," Modern Pathology, vol. 7, no. 6, pp. 690-713, 1994.

[75] J. F. Mosnier, C. Degott, P. Marcellin, D. Henin, S. Erlinger, and J. P. Benhamou, "The intraportal lymphoid nodule and its environment in chronic active hepatitis C: an immunohistochemical study," Hepatology, vol. 17, no. 3, pp. 366-371, 1993.

[76] D. Sansonno, G. Lauletta, V. De Re et al., "Intrahepatic B cell clonal expansions and extrahepatic manifestations of chronic HCV infection," European Journal of Immunology, vol. 34, no. 1, pp. 126-136, 2004.

[77] V. Racanelli, D. Sansonno, C. Piccoli, F. P. D’Amore, F. A. Tucci, and F. Dammacco, "Molecular characterization of B cell clonal expansions in the liver of chronically hepatitis C virus-infected patients," Journal of Immunology, vol. 167, no. 1, pp. 21-29, 2001.

[78] A. Rot and U. H. Von Andrian, "Chemokines in innate and adaptive host defense: basic chemokinese grammar for immune cells," Annual Review of Immunology, vol. 22, pp. 891-928, 2004.

[79] D. F. Legler, M. Loetscher, R. S. Roos, I. Clark-Lewis, M. Baggiolini, and B. Moser, "B cell-attracting chemokine 1, a human CXC chemokine expressed in lymphoid tissues, selectively attracts B lymphocytes via BLR1/CXCR5," Journal of Experimental Medicine, vol. 187, no. 4, pp. 655-660, 1998.

[80] D. Sansonno, F. A. Tucci, L. Troiani et al., "Increased serum levels of the chemokine CXCL13 and up-regulation of its gene expression are distinctive features of HCVrelated cryoglobulinemia and correlate with active cutaneous vasculitis," Blood, vol. 112, no. 5, pp. 1620-1627, 2008.

[81] P. Schneider and J. Tschopp, "BAFF and the regulation of B cell survival," Immunology Letters, vol. 88, no. 1, pp. 57-62, 2003.

[82] E. Toubi, S. Gordon, A. Kessel et al., "Elevated serum BLymphocyte activating factor (BAFF) in chronic hepatitis C virus infection: association with autoimmunity," Journal of Autoimmunity, vol. 27, no. 2, pp. 134-139, 2006.

[83] L. Bonomo, M. Casato, A. Afeltra, and D. Caccavo, "Treatment of idiopathic mixed cryoglobulinemia with alpha interferon," American Journal of Medicine, vol. 83, no. 4, pp. 726-730, 1987.

[84] K. R. Reddy, T. L. Wright, P. J. Pockros et al., "Efficacy and safety of pegylated (40-kd) interferon $\alpha$-2a compared with interferon $\alpha$-2a in noncirrhotic patients with chronic hepatitis C," Hepatology, vol. 33, no. 2, pp. 433-438, 2001.

[85] P. Glue, J. W. S. Fang, R. Rouzier-Panis et al., "Pegylated interferon- $\alpha 2 \mathrm{~b}$ : pharmacokinetics, pharmacodynamics, safety, and preliminary efficacy data," Clinical Pharmacology and Therapeutics, vol. 68, no. 5, pp. 556-567, 2000.

[86] J. Shepherd, H. Brodin, C. Cave, N. Waugh, A. Price, and J. Gabbay, "Pegylated interferon alpha-2a and $-2 b$ in combination with ribavirin in the treatment of chronic hepatitis C: a systematic review and economic evaluation.", Health Technology Assessment, vol. 8, no. 39, pp. 1-125, 2004.

[87] D. B. Strader, T. Wright, D. L. Thomas, and L. B. Seeff, "Diagnosis, management, and treatment of hepatitis C," Hepatology, vol. 39, no. 4, pp. 1147-1171, 2004.
[88] P. Cacoub, D. Saadoun, N. Limal, D. Sene, O. Lidove, and J. C. Piette, "PEGylated interferon Alfa-2b and ribavirin treatment in patients with hepatitis C virus-related systemic vasculitis," Arthritis and Rheumatism, vol. 52, no. 3, pp. 911-915, 2005.

[89] L. Vallat, Y. Benhamou, M. Gutierrez et al., "Clonal B cell populations in the blood and liver of patients with chronic hepatitis C virus infection," Arthritis and Rheumatism, vol. 50, no. 11, pp. 3668-3678, 2004.

[90] H. B. Fan, Y. F. Zhu, A. S. Chen et al., "B-cell clonality in the liver of hepatitis C virus-infected patients," World Journal of Gastroenterology, vol. 15, no. 13, pp. 1636-1640, 2009.

[91] E. D. Charles, C. Brunetti, S. Marukian et al., "Clonal B cells in patients with hepatitis $\mathrm{C}$ virus-associated mixed cryoglobulinemia contain an expanded anergic CD21 $1^{\text {low }} \mathrm{B}$ cell subset," Blood, vol. 117, no. 20, pp. 5425-5437, 2011.

[92] M. C. Cheung, A. E. Haynes, R. M. Meyer, A. Stevens, and K. R. Imrie, "Rituximab in lymphoma: a systematic review and consensus practice guideline from Cancer Care Ontario," Cancer Treatment Reviews, vol. 33, no. 2, pp. 161-176, 2007.

[93] I. Sanz, J. H. Anolik, and R. J. Looney, "B cell depletion therapy in autoimmune diseases," Frontiers in Bioscience, vol. 12, no. 7, pp. 2546-2567, 2007.

[94] W. Barcellini and A. Zanella, "Rituximab therapy for autoimmune haematological diseases," European Journal of Internal Medicine, vol. 22, no. 3, pp. 220-229, 2011.

[95] D. Sansonno, V. De Re, G. Lauletta, F. A. Tucci, M. Boiocchi, and F. Dammacco, "Monoclonal antibody treatment of mixed cryoglobulinemia resistant to interferon $\alpha$ with an anti-CD20," Blood, vol. 101, no. 10, pp. 3818-3826, 2003.

[96] F. Zaja, S. De Vita, C. Mazzaro et al., "Efficacy and safety of rituximab in type II mixed cryoglobulinemia," Blood, vol. 101, no. 10, pp. 3827-3834, 2003.

[97] M. Visentini, S. Ludovisi, A. Petrarca et al., "A phase II, single-arm multicenter study of low-dose rituximab for refractory mixed cryoglobulinemia secondary to hepatitis $\mathrm{C}$ virus infection," Autoimmunity Reviews, vol. 10, no. 11, pp. 714-719, 2011.

[98] C. Ferri, P. Cacoub, C. Mazzaro et al., "Treatment with rituximab in patients with mixed cryoglobulinemia syndrome: results of multicenter cohort study and review of the literature," Autoimmunity Reviews, vol. 11, no. 1, pp. 48-55, 2011.

[99] F. Dammacco, F. A. Tucci, G. Lauletta et al., "Pegylated interferon- $\alpha$, ribavirin, and rituximab combined therapy of hepatitis $\mathrm{C}$ virus-related mixed cryoglobulinemia: a longterm study," Blood, vol. 116, no. 3, pp. 343-353, 2010.

[100] M. Pietrogrande, S. De Vita, A. L. Zignego et al., "Recommendations for the management of mixed cryoglobulinemia syndrome in hepatitis C virus-infected patients," Autoimmunity Reviews, vol. 10, no. 8, pp. 444-454, 2011.

[101] A. S. Lok, D. F. Gardiner, E. Lawitz et al., "Preliminary study of two antiviral agents for hepatitis C genotype 1," The New England Journal of Medicine, vol. 366, no. 3, pp. 216-224, 2012.

[102] J. W. Levine, C. Gota, B. J. Fessler, L. H. Calabrese, and S. M. Cooper, "Persistent cryoglobulinemic vasculitis following successful treatment of hepatitis C virus," Journal of Rheumatology, vol. 32, no. 6, pp. 1164-1167, 2005.

[103] D. A. Landau, D. Saadoun, P. Halfon et al., "Relapse of hepatitis $C$ virus-associated mixed cryoglobulinemia vasculitis in patients with sustained viral response," Arthritis and Rheumatism, vol. 58, no. 2, pp. 604-611, 2008. 
[104] B. D. Cheson, "Ofatumumab, a novel anti-CD20 monoclonal antibody for the treatment of B-cell malignancies," Journal of Clinical Oncology, vol. 28, no. 21, pp. 3525-3530, 2010.

[105] A. Ramunni, G. Lauletta, P. Brescia et al., "Double-filtration plasmapheresis in the treatment of leg ulcers in cryoglobulinemia," Journal of Clinical Apheresis, vol. 23, no. 3, pp. 118$122,2008$.

[106] G. Talamo and M. Zangari, "Novel therapeutic approaches to cryoglobulinemia: imatinib, infliximab, bortezomib, and beyond," in HCV Infection and Cryoglobulinemia, chapter 45, pp. 349-355, Springer, Milan, Italy, 2012.

[107] D. Saadoun, M. Rosenzwajg, F. Joly et al., "Regulatory Tcell responses to low-dose interleukin-2 in HCV-induced vasculitis," The New England Journal of Medicine, vol. 365, no. 22, pp. 2067-2077, 2011. 


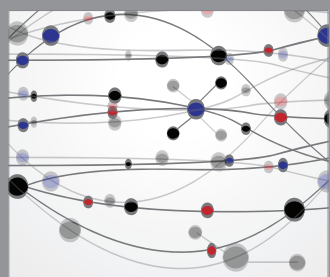

The Scientific World Journal
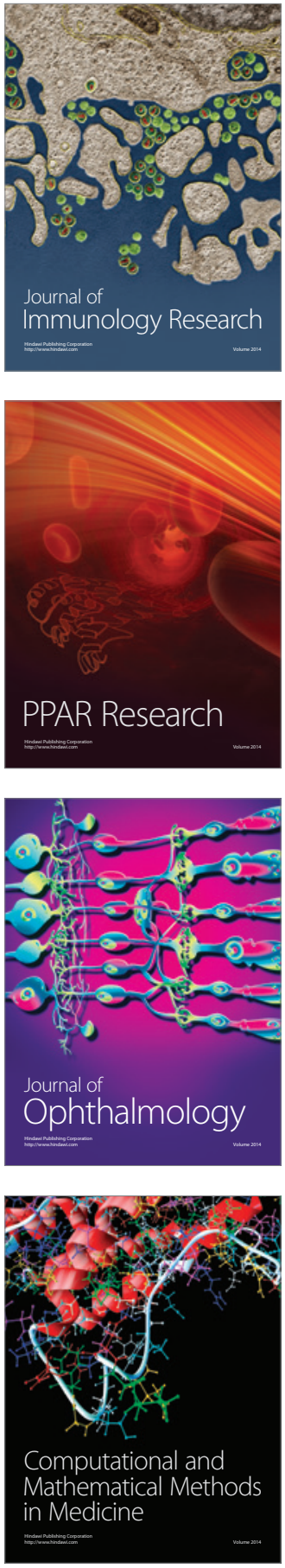

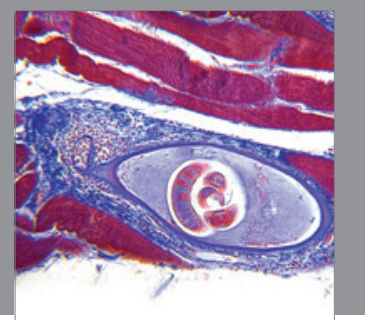

Gastroenterology

Research and Practice
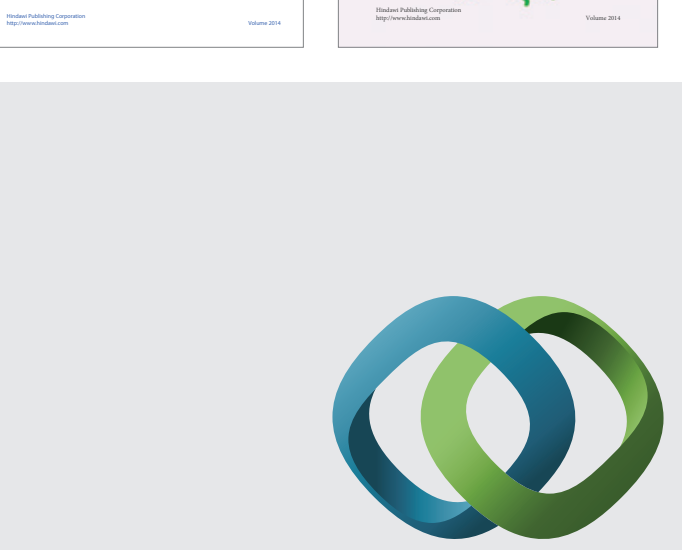

\section{Hindawi}

Submit your manuscripts at

http://www.hindawi.com
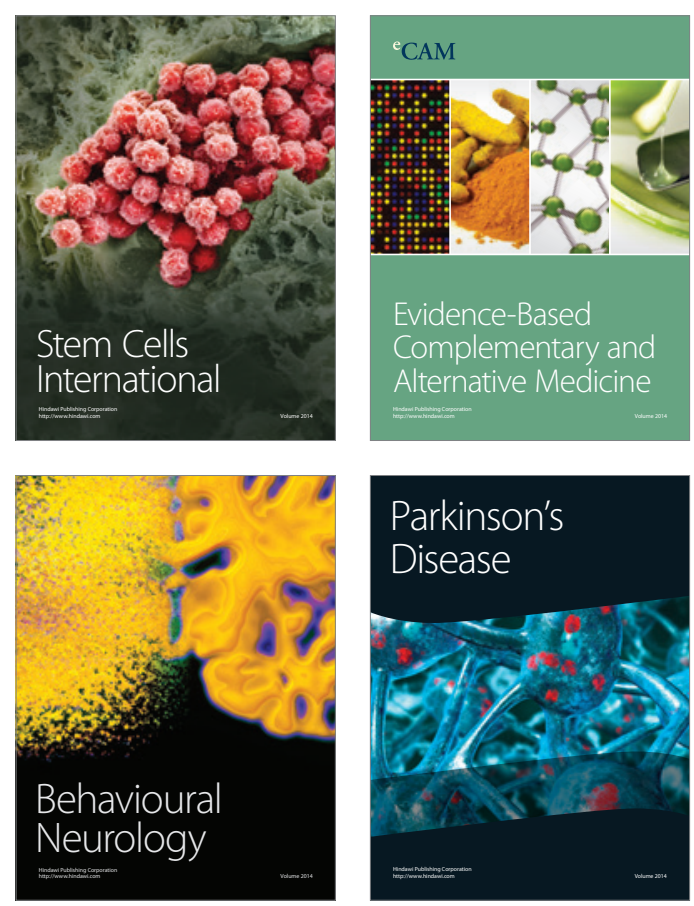

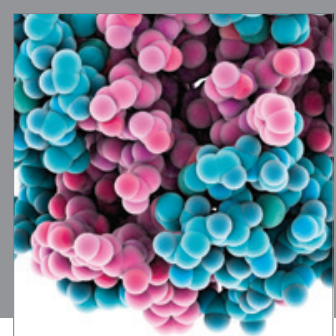

Journal of
Diabetes Research

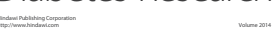

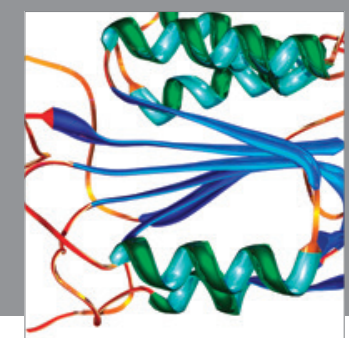

Disease Markers
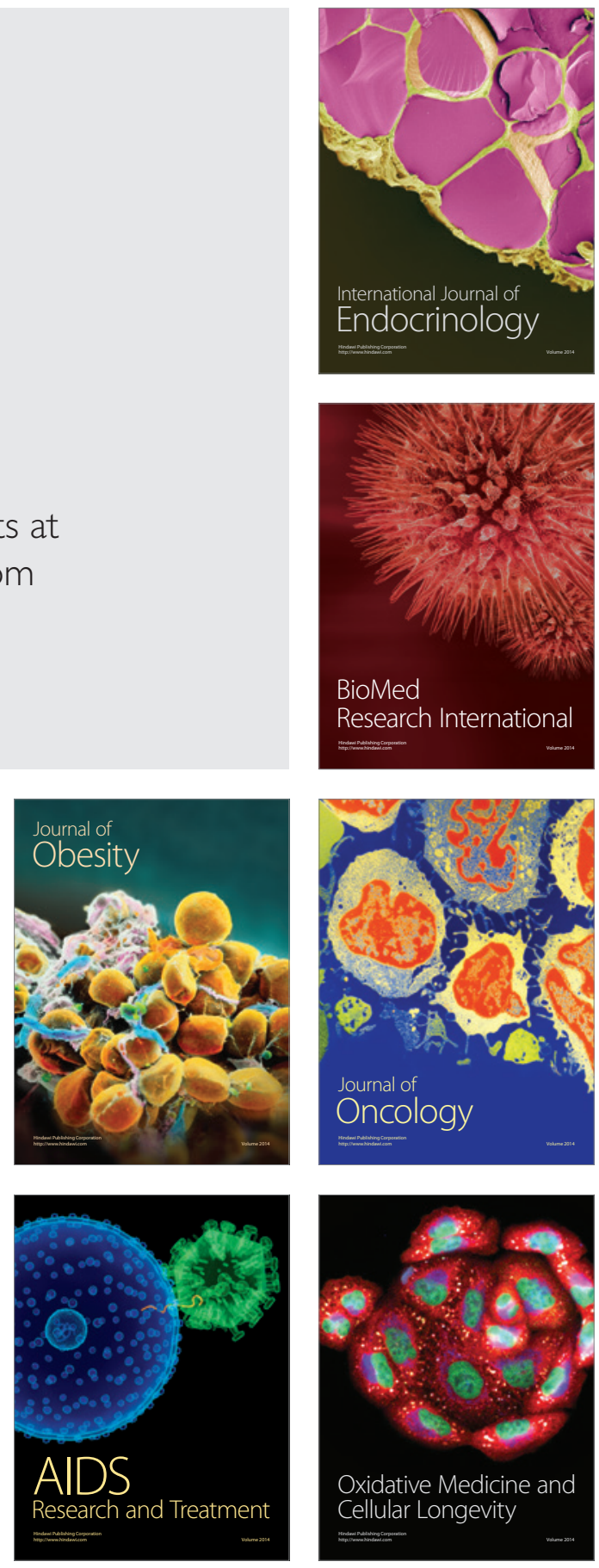